\section{B A Institute of \\ yk Business Administration \\ 六下 \\ Karachi \\ Leadership and Ideas for Tomorrow}

Business Review

Volume 4 Issue 2 July-December 2009

7-1-2009

\title{
Call for Papers: International Conference on Management and Valuation of Intangibles ICMVI 2009
}

Prof. R. C. Sobti

Vice Chancellor, Panjab University, Chandigarh, India

Follow this and additional works at: https://ir.iba.edu.pk/businessreview

Part of the Business Commons

(c) (i)

This work is licensed under a Creative Commons Attribution 4.0 International License.

\section{Recommended Citation}

Sobti, P. (2009). Call for Papers: International Conference on Management and Valuation of Intangibles ICMVI 2009. Business Review, 4(2), 147-154. Retrieved from https://doi.org/10.54784/1990-6587.1338

This article is brought to you by iRepository for open access under the Creative Commons Attribution 4.0 License and is available at https://ir.iba.edu.pk/businessreview/vol4/iss2/12. For more information, please contact irepository@iba.edu.pk. 


\section{News and Views}

\section{International Conference on Management and Valuation of Intangibles ICMVI 2009}

December 22-23, 2009

Venue: Panjab University

Chandigarh-160014

INDIA

CALL FOR PAPERS / CASE STUDIES

\section{ORGANIZED BY}

University Business School

Panjab University

Chandigarh

INDIA

\section{PATRON}

Prof. R. C. Sobti

Vice-Chancellor

Panjab University, Chandigarh-160014

INDIA

\section{CONFERENCE CHAIRS}

Dr. Dinesh K. Gupta

Professor \& Chairman, University Business School

Panjab University, Chandigarh-160014, INDIA

Dr. Deepak Kapur

Professor, University Business School

Panjab University, Chandigarh-160014, INDIA

Dr. Karamjeet Singh

Reader, University Business School

Panjab University, Chandigarh-160014, INDIA 


\begin{abstract}
About the Conference
University Business School (UBS), Panjab University, Chandigarh announces 'International Conference on Management and Valuation of Intangibles'. The value derived for a business organization from intangible assets has considerably increased in the knowledge-based economy of the 21 st century. The wide gap in the market-value and book -value of equity shares of most of the firms is a testimony to the fact that the traditional balance sheet fails to portray the true picture of the assets that generate revenue for an enterprise. The intangible assets like brand value, intellectual property rights etc have become the prime reason for the difference in value of such firms. The motivation of this conference has arisen from the increasing importance of such intangibles in the success of a modern business enterprise.
\end{abstract}

\title{
Conference Objectives
}

* To provide a forum to discuss different types of intangibles and their management including valuation methods;

* To deliberate on the advances in theory and practice regarding management of intangibles;

* To share practical insights regarding the management and valuation of intangibles from corporate world.

\section{Organizers}

University Business School, Panjab University, Chandigarh, has carved out a niche for itself in this highly competitive and globalized business world of today. UBS is one of the oldest business schools of India. It has been imparting quality management education for the last four decades. This institution is known for providing dedicated, motivated and competent management personnel to the corporate world. The teaching-learningmentoring process, the flexibility of approach to meet the challenge of constant change, and balanced all-round development of students are the distinguishing traits of UBS. It has got a highly dedicated and proficient faculty as also excellent infrastructure.

\section{ICMVI 2009 Advisory Committee}

1 Dr. Ali, Anwar, Director,

IMT, Ghaziabad.

2 Dr. Anand, Manoj K., Professor,

IIM, Lucknow. 
3 Dr. Chandra, Akhilesh, Professor, University of Akron, OH, USA.

4 Dr. Chopra, Rakesh, Rear Admiral (Retd .), Professor, XLRI, Jamshedpur.

5 Dr. Dholakia, Ravindra H., Professor, IIM, Ahmedabad.

6 Dr. Flamholtz, Eric, Professor Emeritus, University of California at Los Angeles, CA, USA.

7 Dr. Jain, S. K., Professor, IIT, New Del hi.

8 Mr. Kant, Sudhir, President, Millipore India Pvt Ltd, Bangalore.

9 Dr. Kei, Kuriki, Associate Professor, Kobe University, Japan.

10 Mr. Khanna, Anil, Managing Director, Blue Dart Express Ltd, Mumbai.

11 Mr. Khoi, Tran Anh, Best Practice Manager, Vietnam Prod uctivity Centre, Hanoi, Vietnam.

12 Dr. Kumar, Sanjay, Professor, XLRI, Jamshedpur .

13 Dr. Lee, Jinyong, Professor, Seoul National University of Technology, Seoul, South Korea.

14 Dr. Lev, Baruch, Professor, Stern School of Business, New York University, NY, USA. 
15 Dr. Lou, Yung-Chein, Secretary General, National Chengchi University, Taipai, Taiwan.

16 Dr. Maheshwari, G. C., Dean \& Professor, Faculty of Business Management, MSU, Vadodra.

17 Dr. Mohanty, B. K., Professor, IIM, Lucknow.

18 Dr. Mohanty, Pitabas, Professor, XLRI, Jamshedpur.

19 Dr. Narayaswamy, R., Professor, IIM, Bangalore.

20 Mr. Ng, Andrew, Chief Executive Officer, Greater China Consult, Singapore.

21 Dr. Parkash, Mohinder,Associate Professor, Oakland University, MI, USA.

22 Dr. Prabhu, Ganesh N., Associate Professor, IIM, Bangalore.

23 Dr. Ray, Pranabesh, Professor, XLRI, Jamshedpur.

24 Dr. Riahi-Belkaoui, Ahmed, Professor, University of Illinois at Chicago, USA.

25 Dr. Saeed, Mohammad, Professor, Minot State University, USA.

26 Dr. Saha, Debashis, Professor, IIM, Ahmedabad

27 Dr. Sahay, Bidya S., Director, MDI, Gurgaon. 
28 Dr. Sharma, Meenakshi, Associate Professor, IIM, Ahmedabad

29 Dr. Singh, Devi, Director, IIM, Ahmedabad

30 Dr. Vaidya, Rajendra, Professor, IGIDR, Mumbai.

31 Dr. Vaidya, Rajendra, Professor, IGIDR, Mumbai.

\section{Organizing Committee}

1 Dr. Bawa, Anupam, Professor, UBS, PU, Chandigarh.

2 Dr. Chadha, S. K., Professor, UBS, PU, Chandigarh

3 Dr. Malhotra, Keshav, Professor, PU, Chandigarh.

4 Dr. Malhotra, Meenakshi, Professor, UBS, PU, Chandigarh.

5 Dr. Vaidya, S. C., DUI (PU) \& Professor, UBS, PU, Chandigarh.

6 Dr. Vashisht, A.K., Professor, UBS, PU, Chandigarh.

\section{Important Dates}

Abstract Submission

Notification for Acceptance of Abstracts Full Length Paper/ Case Study Submission Last Date of Registration for the Conference
August 31, 2009

September 21, 2009

October 31, 2009

November 15, 2009 
Conference Inauguration

Conference Dinner

Valedictory Session
December 22, 2009

December 22, 2009

December 23, 2009

\section{Registration Fee}

$\begin{array}{llll} & \begin{array}{l}\text { Doctoral } \\ \text { Students }\end{array} & \text { Academics } & \text { Industry } \\ \text { National } & \text { INR 1000 } & \text { INR 2500 } & \text { INR 4000 } \\ \text { International } & \text { USD 50 } & \text { USD 100 } & \text { USD 200 }\end{array}$

Registration is required even if the paper is selected for the conference. At least one author must register for the paper to be included in the conference proceedings. The registration fee covers the conference kit, conference proceedings, conference dinner, lunch and tea. It, however, does not include hotel accommodation, hotel pickups, and airport transfers. Registration fee can be paid by a demand draft drawn in favor of the 'Chairman, University Business School', payable at Chandigarh. The demand draft along with completed registration form should be sent by post to Dr. Deepak Kapur, Conference Chair, supper scribing ICMVI 2009 on the envelope. Registration fee, once paid, would not be refunded.

\section{Guidelines for Abstract Submission}

Selection of papers for presentation would be based on abstracts of about 750 - 1000 words. The author(s) should clearly mention the area of interest under which the abstract is to be included. The abstracts would be blind reviewed by experts and only those abstracts that get approved would be selected for final paper submission. All contributions should be submitted in English in Times Roman 12-point type, 1.5 lines spacing in A4 size page setup, with margins of one inch from all sides. Abstract should be accompanied with a certificate by the author that the paper is the author's own work and has neither been published nor submitted for publication elsewhere. The cover page of the paper should contain: (i) title of the paper (in bold) (ii) name(s) of author(s) (iii) author(s) professional affiliation (iv) address for correspondence with email and telephone number(s). Please note that the authors name should not be mentioned on any other page than the cover page.

\section{Case Studies}

Selection of case studies would be based on abstracts of about $750-1000$ 
words. The abstracts must clearly indicate the objective of the case study, details of the organization for which the case is written, major findings, implications, and key references. Only case studies of real-life organizations would be considered. The author should clearly mention the area of interest of the conference under which the case study is to be included. Both academicians and corporate managers are expected to contribute to the conference case studies. Each case study based on primary data should include 'A No -Objection Certificate' from the organization for which the case study is written. The case study submissions would also be required to have a detailed 'Teaching Note'.

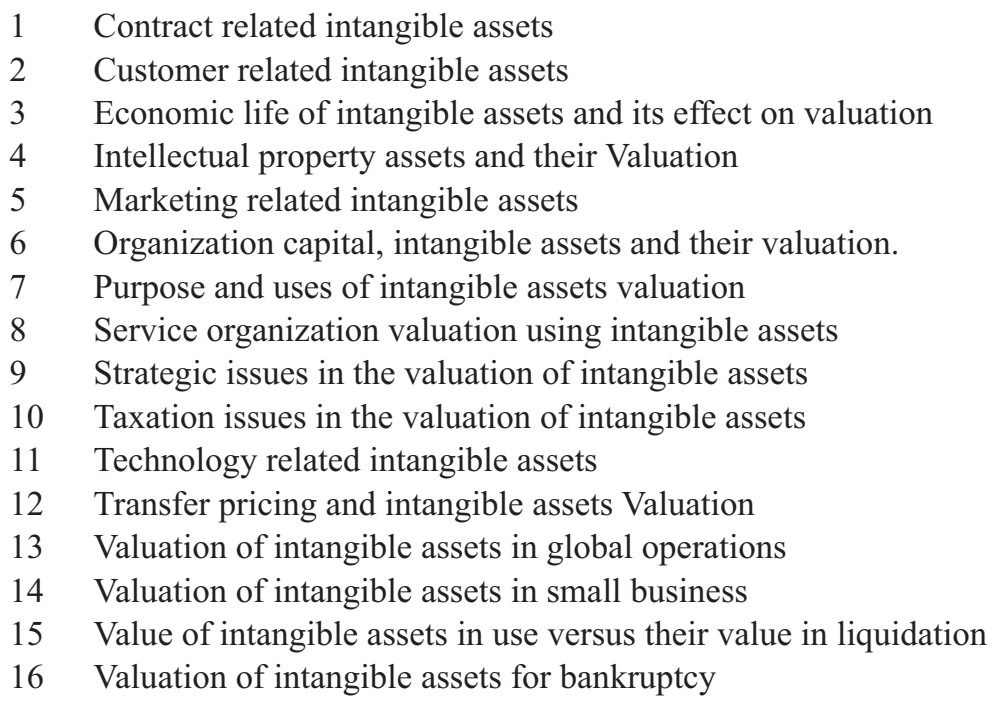

\section{PROFILE OF THE CONFERENCE CHAIRS}

Dr Dinesh K. Gupta is a PhD in Accounting and Finance from the Panjab University, Chandigarh. He is at present Chairman - UBS, besides being Professor of Accounting and Finance at the UBS, PU, Chandigarh. Presently, he is also the Dean of Faculty of Business Management and Commerce, Panjab University, Chandigarh. Professor Gupta has earlier taught in reputed BSchools like the IIM-Lucknow, MDI-Gurgaon etc.

Dr Deepak Kapur is a Fellow of the Indian Institute of Management, Ahmedabad. He is Professor of Strategic Management at the UBS, PU, Chandigarh. He has also taught in reputed B-Schools like the XLRI-Jamshedpur, SPJIMR-Mumbai, IMT-Ghaziabad, XLRI-AIT Dubai etc.

Dr Karamjeet Singh is a $\mathrm{PhD}$ from the Guru Nanak Dev University, Amritsar. He is 
presently working as a Reader in the UBS, PU, Chandigarh in the area of Accounting and Finance and is an expert in Strategic Cost Management. He has also taught in reputed Institutes.

\section{CONTACT US:}

\section{DR DINESH K. GUPTA}

Chairman \& Professor (Accounting and Finance),

University Business School,

Panjab University,

Chandigarh-160014, INDIA.

Email: dkgupta@pu.ac.in

Phone: +91-172-2534709; Fax: +91-172-2541591

\section{DR DEEPAK KAPUR}

Professor (Strategic Management),

University Business School,

Panjab University,

Chandigarh-160014, INDIA.

Email: dkapur@pu.ac.in

Phone: +91-172-2534703

Mobile: +91-9417006837

\section{DR. KARAMJEET SINGH}

Reader (Accounting and Finance),

University Business School,

Panjab University,

Chandigarh-160014, INDIA.

Email: krjsingh@pu.ac.in

Phone: +91-172-2534714

Mobile: +91-9876107 